Wayside Shrines: Everyday Religion in Urban India

\title{
Spatiality, Memory and Street Shrines of Amritsar
}

\section{Yogesh Snehi}

\section{OpenEdition}

\section{Journals}

Electronic version

URL: http://journals.openedition.org/samaj/4559

DOI: $10.4000 /$ samaj.4559

ISSN: 1960-6060

\section{Publisher}

Association pour la recherche sur l'Asie du Sud (ARAS)

\section{Electronic reference}

Yogesh Snehi, «Spatiality, Memory and Street Shrines of Amritsar », South Asia Multidisciplinary Academic Journal [Online], 18 | 2018, Online since 29 May 2018, connection on 30 April 2019. URL : http://journals.openedition.org/samaj/4559; DOI : 10.4000/samaj.4559

This text was automatically generated on 30 April 2019

\section{(c) (i) $\odot$}

This work is licensed under a Creative Commons Attribution-NonCommercial-NoDerivatives 4.0 International License. 


\title{
Spatiality, Memory and Street Shrines of Amritsar
}

\author{
Yogesh Snehi
}

This paper explores popular Sufi shrine practices and associated semiotics at Amritsar (India) to make sense of debates on religion in South Asia. I argue that rather than following the "sedimentary" theories of religious change, we need to consider "popular" religion as overlapping layers of religious practices that delineate the lived and the everyday and spatialize faith practices in modern South Asia. ${ }^{1}$ The historiography of religion in Punjab has predominantly focused on polemics, for instance, around Gurdwara Reform movement. Through the colonial framework of theology, this historiography proposes fixity of religious boundaries that have supposedly remained historically impenetrable. Amritsar is thus principally associated with the Golden Temple (popularly called Darbar Sahib) as a major center for "Sikh" veneration and more recently Durgiana temple as a central shrine (tirath in Punjabi) for urban "Hindus." While the Golden Temple emerged in Mughal India, Durgiana Temple emerged in the early twentieth century as a result of religious reform movements that led to polemical debates on territorialization of religious boundaries in South Asia. However, Amritsar is also dotted with unique street shrines that defy easy classification as "Hindu," "Sikh" or "Muslim" shrines and practices. These shrines are a blend of pre-partition and contemporary shrine practices. The city memorializes several Sufi mystics each year through urs celebrations in the memory of Sakhi Sarwar (Baba Lakhdata), Baba Farid, Khwaja Khizr (Jhule Lal), Sabir Pak, Gauz Pak and local pirs that transform the streets of the Amritsar, engaging people from diverse spectrum of caste, class and religious hierarchies. These practices continue to define the contours of sacred space in urban India that is predominantly projected to be etched in communal stereotypes.

2 Much of the fieldwork utilized in this article was part of the decade-long project on understanding popular Sufi shrines in post-partition Punjab. A major part of this research was pursued between the year 2006-11 when I taught at a college in Amritsar that was located inside the walled city. Hailing from the periphery of Indian Punjab, Amritsar to me was, as to most others, a city singularly and uniquely identified as center of "Sikh" 
veneration. Understanding the city through the "neat" lenses that I was trained in seemed impossible. I looked for theoretical models that could explain a tutored eye, "uncanny" aspects of the sacred in the city space. This bewilderment led to an exploration of continuities and changes at fluid sacred spaces in Amritsar. This paper attempts to foreground one aspect of street shrines, among several complex contours of social space and the post-partition city. A significant part of this paper is an attempt to map the spatial contours of the city pre-partition when it was also a Muslim dominated urban center. However, the street shrines chosen for the paper are located within the walled city which was predominantly non-Muslim, and my research involved documenting and decoding location, neighborhood, festivals, rituals and iconography of popular saints who are venerated at these street shrines. The following discussion is not an attempt to disentangle but rather understand histories of faith practices that are entangled and "hybrid," using Bruno Latour's notion of the social (Latour 1993).

\section{A City in a Nationalist Historiography}

Established by Guru Ramdas (d. 1581), Amritsar owes its name to a sacred tank (amrit sar or pool of nectar) in the middle of which was laid the foundation of the holiest of "Sikh" religious shrines by a Qadiri Sufi mystic of Lahore Miyan Mir in 1588. The "Sikh" historiography acknowledges the role of Sufi mysticism in the Sikh tradition through the inclusion of Baba Farid's mystical poetry (Fariduddin Ganj-i-Shakar, a Chishti Sufi saint of Pakpattan who died in 1266) in the Guru Granth Sahib, but doesn't go further than this. ${ }^{2}$ Thus, in the historiography of contemporary "Sikh" tradition, Baba Farid, for instance, remains peripheral. Yet the Punjabi Sufi saint is vibrantly present in popular commemorative practices ${ }^{3}$ and this intimate relationship between "Sikh" Gurus and Sufi saints continues to resonate in the popular memory post-partition.

the turbulent period of the 1940s when sajjādā nishins (hereditary caretakers) of many important branches of Sufi shrines of Punjab began shifting their political allegiance from the British to the Muslim League and paved the way for Partition of the large province. ${ }^{4}$ The trouble had started way back in the early twentieth century when reformers had begun targeting shared sacred sites. Sufi saint veneration and visitation of shrines was critically argued as not just un-Islamic, but also against the perceived textual tenets of Sikhi. ${ }^{5}$ It is important to note that reform movements and politics over shrines significantly defined the fate of South Asia. ${ }^{6}$ The new ways in which religion and practices were perceived, the pertinent ways in which the "self" was being redefined and the "other" articulated, characterized the elite intellectual polemics of public spaces. ${ }^{7}$ Often, these elite claims and conflicts occupied the emerging public sphere, thereby redefining the terms of public engagement (Veer 2001:14-29). Almost a century later, these polemics continue to define the trope of contemporary historiographies.

5 Dominant historiography on Amritsar in the twentieth century has been influenced by two major factors. One is the obvious centrality of the Golden Temple, but more significant is the movement for Gurdwara Reform (Singh 1922; Singh 1978; Murphy 2012). In the early 1920s this non-violent movement for Tat Khalsa (a reformist "Sikh" faction) control over management of Gurdwaras evoked a strong nationalist response. Gandhi extended Congress's support, which strengthened both the Gurdwara Reform and the non-cooperation movement against the colonial government. This nationalist 
appropriation of a movement for control over "Sikh" religious shrines has remained etched in post-partition historiography, thereby almost erasing the role that "other" narratives play in shaping city's history. Nationalist historiography also evoked a major response to the Jallianwala Bagh massacre in Amritsar in 1919, which previously offered a strong resistance to the British government and laid the foundation for the freedom movement (Tuteja 1997; Datta and Settar 2000; Collett 2005). Focused histories on the city also follow a similar tropology (Datta 1967; Singh 1984; Gauba 1988). Spatially too, the twin sites of the Golden Temple and Jallianwala Bagh assume the most significant aspect of city space, connected to the nationalist imagination. One of the relatively recent works on the Epicentre of Violence, edited by Ian Talbot and Darshan S. Tatla (2006), captures the city in the midst of partition violence and opens up a rare reading on memories of the city and religious communities pre-partition. Through a reading of select reformist narratives from Talbot and Tatla, I will attempt to problematize ahistorical presuppositions on religious identities and contact, and the narrative of changes that urban and rural landscapes have undergone post-partition, thereby contemporizing historical narratives as much as spatializing them.

\section{Contextualizing Lived Spaces}

Scholarly readings of sacred shrines in South Asia have predominantly focused on the major shrines and their ritual practice. In Punjab, Golden Temple occupies a prominent position in the "nationalist" as well as more recent communal historiographies. Most of these readings do not consider the "space" within which shrines are embedded. A fundamental obsession with the convenient tropes of structures, symbolism and political economy fails to consider the significant historical role that "space" and the everyday also play in the emergence of cult of shrines. The problem gets further complicated when focus shifts to an understanding of such popular shrines that lack any significant documented history of their establishment and evolution. In the case of such shrines, an exploration of "space" becomes all the more crucial. In his seminal work The Production of Space, Henri Lefebvre (1991) argues that:

every social space is the outcome of a process with many aspects and many contributing currents, signifying and non-signifying, perceived and directly experienced, practical and theoretical. In short, every social space has a history, one invariably grounded in nature, in natural conditions that are at once primordial and unique in the sense that they are always and everywhere endowed with specific characteristics (site, climate, etc.). (P. 110) ${ }^{8}$

Michel de Certeau further argues that "spatial practices in fact secretly structure the determining conditions of social life' and therefore, any 'theory of everyday practices, of lived space, of the disquieting familiarity of the city" (Certeau 1988:96). Lefebvre elaborates the fluidity of spatiality:

When the history of a particular space is treated as such, the relationship of that space to the time which gave rise to it takes on an aspect that differs sharply from the picture generally accepted by historians [for instance, pre and post partition space in Amritsar]. Traditional historiography assumes that thought can perform cross-sections upon time, arresting its flow without too much difficulty [take for instance the assumed absolute role of movement for social and religious reform on the notion of scared]; its analyses thus tend to fragment and segment temporality. In the history of space as such, on the other hand, the historical and diachronic realms and the generative past are forever leaving their inscriptions upon the writing-tablet, so to speak, of space [as script of the past that keeps enriching the 
contemporary social space, but at the same time scandalize the rhetoric of reform]. The uncertain traces left by events are not the only marks on (or in) space: society in its actuality also deposits [like a discomforting residue in the nationalist sense] its script, the result and product of social activities (Lefebvre 1991:110).

Thus, popular shrines are a kind of "bridge of [historical] understanding" (Humboldt 1985:112, cited in Chakrabarty 2000:109) which contemporizes pasts, as a "living memory", and "carries within itself both survivals from previous eras and the possibility for further change" (Moran 2004:56). Popular shrines offer an important opportunity to explore everyday religion through what Certeau terms "procedures of consumption"-the "use made by the "common people" of the culture disseminated and imposed by the "elites" producing the language" (Certeau 1988: xiii). "These "ways of operating" constitute the innumerable practices by means of which users reappropriate the space organized by techniques of sociocultural production" (Certeau 1988: xiv). Significantly, "everyday" is absent both from the annals of the archives and the "spectacularizing discourse of modernity" (Moran 2004:54). Moran (2005) sees it as a residual, overlooked material which is repetitive, peripheral, uncanny and uneventful, and hence invisible. He thus makes a case for “everyday" by foregrounding Gramsci's (1971) spontaneous philosophy:

those forms of lay knowledge that, by virtue of being so firmly embedded in specific social contexts, conceal resilient power relationships. In this context, "the everyday" is a space where practice and representation are complexly interrelated, where the lived reality of the quotidian co-exists with clichés, mythologies, stereotypes and unsourced quotations. (Moran 2005:12)

Popular shrines can thus be studied not just as "timeless and pristine objects", but as "products of the restless operation of both internal dynamics ... [for instance social space pre and post-partition] and external forces ... [like colonialism and post-partition reorganization of the social space] over time" (Ortner 2006:9). It is in the "culturally organized practices" of everyday life and memory that the dialectics of social life can be understood. Paul Connerton finds a significant connection between memory and spatiality through performance of "commemorative ceremonies" (Connerton 2011:338). Reading sacred practices through street shrines thus disrupts the accepted nationalist and communal narrative, and provides alternative imagination of social space, one that, for instance, spatializes post-partition Amritsar and also narrates the survivals of prepartition memory. Thus, the "spatialities of religion can help us to understand its [sacred] histories" (Brace, Bailey, and Harvey 2006:31). ${ }^{9}$ Spaces may be read, therefore, not only as sacred or profane, ${ }^{10}$ but also as the "reflections and reproductions of religious and social desires and anxieties" (cited in Brace et. al. 2006:30).

7 Space is also "dynamic, in terms of its relationship to power, history and time, ${ }^{11}$ its condition of simultaneity and the various ways in which it is experienced and represented." It is not a "passive container or backdrop for human activity" (Knott 2008:12). Street shrines of Amritsar, therefore, present a dissenting form of sacred practice located in the midst of two significant sacred shrines of Golden Temple and Durgiana Temple that were entrenched in dominant political discourses of Tat Khalsa and "reformed" Hinduisms since the 1920s. It has become increasingly important to extend the study of religion to spaces outside of the institutional structures and explore its manifestation in everyday spaces and rituals; bazaars, along the road shrines, popular production of images, posters, audio-visual material, souvenirs, etc. As the following discussion will illustrate, urs and ziārat (pilgrimage) are occasions where boundaries between the participants and observers are blurred. The power (barkat) implicit in 
memorial spaces/graves gets legitimized through these rituals. This blurring and overlapping is the everyday corrective to the linear historical discourses.

\section{Demography, History, Memory}

8 According to demographic data available since the nineteenth century, Amritsar was largely a "Muslim" dominated town. However, their presence was particularly marked along the outer edges of the walled city. "Hindus" and "Sikhs" dominated the inner zones (katrās) of the walled city. Muslims in 1852 comprised about 49 per cent of the total population of the city, 9 per cent more than that of its own district. The Sikhs constituted 15.05 per cent of the total population of the city in 1941 (Gauba 1988:262). Anand Gauba observes that,

Their [Muslim] number can be safely estimated at more than 40,000 ... Thus one could find Muslim traders and shopkeepers in the heart of the old city like Bazar Sheikhan adjoining Guru Bazar. The Muslim priestly class had also their residential localities in old Amritsar: Kucha Qazian, Kucha Ragian and Rababian who sang and played celestial music were such examples. But Muslims in general had mostly settled in the outermost quarters of the city, close to the wall like katras Khazana, Hakiman, Karan Singh, Garbha Singh. (Pp. 25-26)

Historically, the land on which the city emerged was owned by a mixed community of "Muslim" Syeds, Sheikhs, and Rajputs. The Tomb of Syed Fateh Ali Shah, one of the former "owners" of the site, is located outside the fort of Govindgarh, to the west ( Gazetteer of the Amritsar District, 1892-93:149). The site of Golden Temple was first purchased by the fourth Sikh guru, Guru Ram Das. ${ }^{12}$ The city was limited to the periphery of Golden Temple which was founded by Guru Arjan in 1588. The major expansion of the city took place during the time of Ranjit Singh who got the wall constructed around the city (Singh 2000:117-24). Besides two important mosques that were located in the hall bazaar, "Muslim" religious places were predominantly located outside of the walled city. The Jami Masjid was outside the Rambagh Gate, several takiās ${ }^{13}$ were located outside this city wall; for instance, those of Pir Shah, Bahar Shah, Noor Shah, Jane Shah, Miraj-ud-Din. Some of the takiās also had khānqahs attached to them (Gauba 1988:16). ${ }^{14}$ Before the partition, the principal "Muslim" gathering is said to have been at Kotli Shah Habib, the shrine of the saint near Ramdas in the Ajnala Tahsil. After the partition of Punjab, at least until the 1970s, no such gathering was held; nor was a fair was held at the shrine of any other "Muslim" saint in the district (Punjab District Gazetteer, Amritsar 1976:93). Gradually, fairs dedicated to saints like Baba Sher Shah Wali started at Gharyala (Patti), Baba Bakhar Ali Shah was held at Khutril Kalan (Ajnala) and Takiya Baba Rodey Shah at Chung (Patti). One should be wary of representations of religious identities of medieval saints and their shrines as exclusive and impenetrable domains of religious boundaries. Sufi shrines particularly defied these exclusivities. ${ }^{15}$

9 It will thus be intriguing to understand how ritual practices at these popular Sufi shrines were reinstated. I will also try to analyze the cultural flow of faith practices before partition and its continuity in contemporary Amritsar. According to the Census of 1941, there were 657,695 Muslims residing in the district, whereas their number post-partition in 1951 was found to be just 4,585. ${ }^{16}$ The district accommodated only 332,260 refugees, leaving a gap of $320,850 .{ }^{17}$ The newcomers who resettled in the district were far fewer in number than the outgoing Punjabi Muslims who were residing in the district (Punjab District Gazetteer, Amritsar 1976:120). ${ }^{18}$ Post-partition historiography does not attest to 
any significant presence of Muslims or Islamicate influence in the lives of people of the walled city pre-partition. Let me cite one important work on Amritsar's memory during Partition. Among the interviews edited by Talbot and Tatla (2002) of prominent non-"Muslim" Punjabis of Amritsar post-partition, none talks about the cultural flows between the inhabitants of the city, "Muslims," "Hindus" and "Sikhs," pre-partition. ${ }^{19}$ Vaid Vidya Sagar a prominent Arya Samaji, who lived in Amritsar since 1922, answers to a question about relations between "Hindus", "Sikhs" and "Muslims" in Amritsar:

They were not bad prior to 1947. Karmpura, Faizpura, [Hussainpura] were near the Mental Hospital, had almost 80 per cent Muslims and there used to be very cordial relations between us. The Muslims were mostly workers, construction worker, or engaged in other kinds of labour [labor]. But they all lived well with each other. (Talbot and Tatla 2006:213)

When asked about occasions when communities came together and reasons for deterioration in relations with other, he says;

There was no such occasion. Sometimes, Hindu and Sikhs would get together, but not with Muslims. Usually, the Muslims would not mix with the Hindus.

Actually, it started with a massacre in the walled city. You see, most Sikhs and Hindus were settled in the walled city, while Muslims generally lived in the outer area. So it happened that we could not move out of our part of the city, while they could not get into our part. So, the difficulties started. All our business was inside the walled city, while Muslims lived in such areas as Karmpura, Faizpura, etc. (Talbot and Tatla 2006:214-15)

The narratives around this period either deny the possibility of cultural flows or completely omit it. One may therefore ask whether there existed possibilities of popular convergence around religious traditions, even while the city was charged with rising tide of social and religious reform during the late nineteenth and early twentieth century. My surveys suggest that many shrines that were earlier under the control of "Muslim" caretakers remained desolate for almost a decade post-partition, at least until 1964, the year in which the Central Wakf Council was established..$^{20}$ Even when taken over by a new set of caretakers, restoration of ritual practices took a longer time. Much of these sacred spaces which consisted of mosques, dargahs, khanqahs, takiyas or graveyards remained desolate or were encroached upon and put to alternative private use. However, it is curious to note that dargahs, khanqahs and takiyas associated with major Sufi mystics or local saints of Punjab were either restored of their ritual practices within the early decades post-partition or were gradually rejuvenated through the agency of some individuals or local community of practitioners of Sufi saint veneration. The restoration of ritual practice at Sufi shrines was a long-drawn process and involved absorption of the shrines into the transformed demographic milieu as old patrons left for Pakistan. ${ }^{21}$ In the context of Amritsar, urs at one of the oldest shrines, that of Syed Fateh Ali Shah situated outside the walled city of Amritsar, was started in the year 2004, more than five decades after the partition of the province. Some of these shrines were major centers of veneration in the pre-partition milieu. For the people who were leaving their familiar spaces in Pakistan, the location of these shrines at least partially substituted their earlier lived landscapes..$^{22}$ The scenario was different for smaller street shrines dedicated to popular Sufi mystics. Such shrines were particularly located inside the walled city and resonated the continuity of pre-partition cultural flows. One of the prominent saints associated with these shrines was Khwaja Khizr or Jhule Lal. 


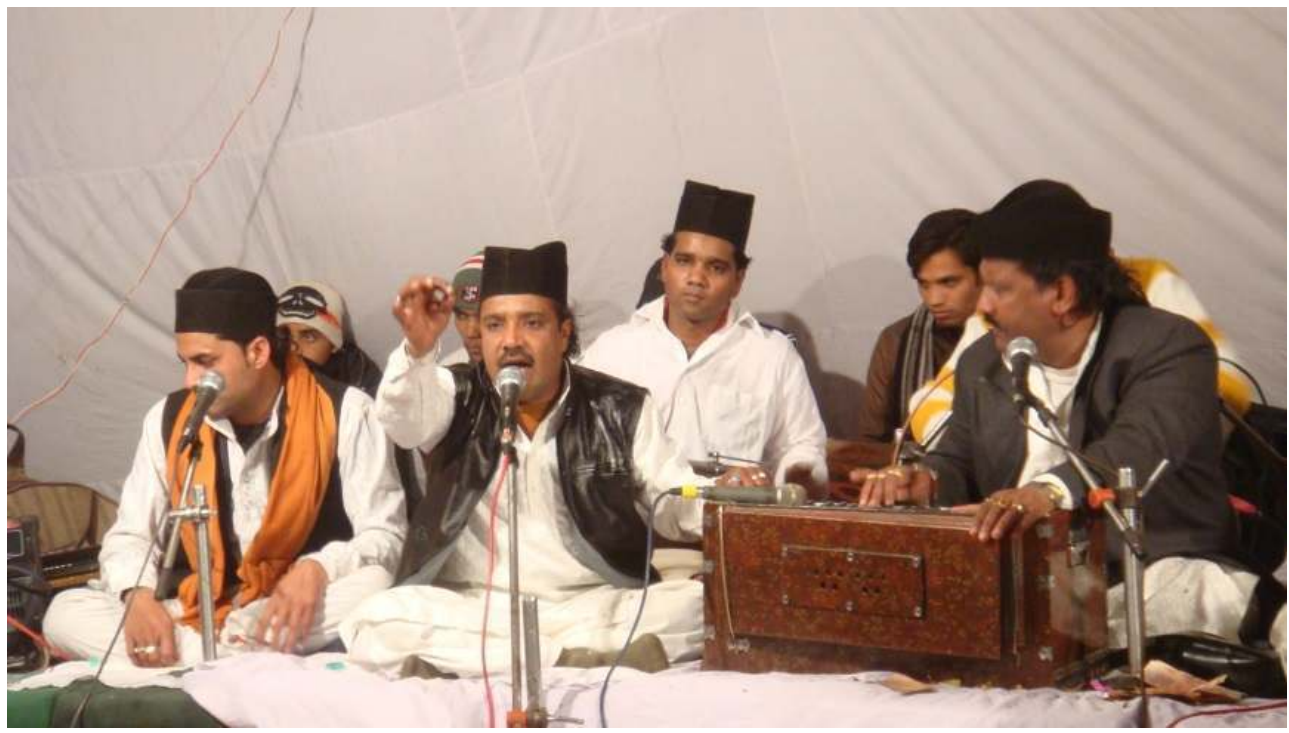

Darbari qawwals from Kaliyar Sharif performing at Amritsar

(Photo by author)

A fascinating aspect of this rejuvenation was the beginning of urs celebrations in the memory of Sufi shrines in the streets of Amritsar (Image 1). Urs has been a predominant occasion of celebration at most Chishti, Qadiri and Suhrawardi shrines and is particularly associated with samā and qawwāli ${ }^{23}$ Since the pir's tomb is present on an earthly plane, he is accessible to ordinary believers. Also, precisely "because the pir has achieved his 'urs (union with his beloved, the ultimate goal of Sufi Gnostic experience), he is in far closer communion with Allah than a living person could ever hope to be. Hence his capacity to act as an intercessor" (Ballard 2006:164). ${ }^{24}$ Contemporary Amritsar is particularly popular for the veneration of popular saints like Baba Lakhdata (Lalanwala Pir Nigaha), Khwaja Khizr (locally venerated as Jhule Lal), Gugga Pir (also popular as Zahir Pir) and Gauz Pak (Shaikh Abdul Qadir Jilani).

\section{Spatializing Khwaja Khizr (Jhule Lal)}

Khwaja Khizr or Khidr has complex histories associated with the religious traditions of the Middle East and South Asia, traversing trade and transregional religious networks. The river cult might have had its origin in the indigenous population and the mercantile communities might have played an important role in its propagation. As a giver of waters of immortality, Khizr is also known as Jinda or Zinda Pir (one who never dies), a title which is, however, more often used for Gugga (Rose 1911:562). In many parts of India Khwaja Khizr is identified with a river god or spirit of wells and streams, revered both by Hindus and Muslims. Synonymously identified with the river Indus, he is seen as an old man clothed in green whose principal shrine is on an island of the river near Bakhar (Sind Revisited 1877:226 cited in Dames 1997:908).

There is ample folk evidence attesting to the relationship of Khwaja Khizr with wells. Crooke details these in relation to the digging of wells in Punjab which was considered "a duty requiring infinite care and caution" (Crooke 1896:48). 
The work should begin on Sunday, and on the previous Saturday night little bowls of water are placed round the proposed site, and the one which dries up least marks the best site for the well ... The circumference is then marked and they commence to dig, leaving the central lump of earth intact. They cut out this clod of earth last and in the Punjab call it Khwajaji, perhaps after Khwaja Khizr, the water god, worship it and feed Brahmans (Crooke 1896:48-49).

The existence of such rituals associated with the digging of wells significantly corroborates evidence regarding the prevalence of large number of Persian wheels in medieval Punjab, which played a major role in extracting water from wells and irrigating large parts of Punjabi landscape. Punjab's transformation from agro-pastoralism to settled agriculture is attributed to the role played by well irrigation and Persian wheels. ${ }^{25}$ The core areas which experienced this transformation also provided fertile ground for the rise of Sikhism. It is interesting to note that several Sikh gurus invested in the digging of wells for both ritual and irrigation purposes. Some of the early Gurdwaras associated with Sikhism were also associated with water bodies-Golden Temple at Amritsar (pool of nectar), Baoli Sahib (step well) at Goindwal and Chehereta Sahib (well with six Persian wheels near Amritsar), to mention a few that were established in the sixteenth century. Fish survive as an important residue of Khwaja Khizr/Varun devta in water bodies in gurdwaras of Punjab. Their ubiquitous presence is a reminder of the significant presence of the cult in the period before the rise of "Sikh" practices. It is not a surprise that most water bodies, ponds as well as stepwells, associated with significant gurdwaras have also been associated with the power of healing skin diseases, particularly leprosy. The popular practice of ritual bathing is associated with these water bodies, once again an adaption of earlier religious practices linking bathing with healing and immortality.

Of particular interest are wells dedicated as shrines to Khawja Khizr or Jhule Lal in Amritsar. Several localities in the walled city of Amritsar are named after wells (khu)Khu Kuhadian, Bombay wala Khu, Khu Suniarian, Chatti Khu, to name a few. Major shrines dedicated to the saint are located on/along the prominent sources of water, primarily wells of the city. According to an estimate from 1892-93, the drinking water in Amritsar was entirely obtained from around 1,400 wells (Gazetteer of the Amritsar District, 1892-93:148). Most of these wells are no longer extant but among those which exist, many have shrines dedicated to Khwaja Khizr or Jhule Lal. ${ }^{26}$ The ubiquitous presence of Jhule Lal in Amritsar problematizes the belief that Jhule Lal is a predominant saint/deity of Sindhis who have negligible presence in Punjab. In the case of Sindhis, Dominique-Sila Khan informs us that "a strong feeling of otherness has prompted them to search for a distinct identity that would help them integrate into the Indian state while preserving their own cultural heritage. In this way the saint and deity Jhulelal, also known as Khwaja Khizr, has become a new marker of their identity" (Khan 2008:72). But in Amritsar, Jhule Lal has a long historical association and is recognized as a hybrid deity.

Image 2

South Asia Multidisciplinary Academic Journal, 18 | 2018 


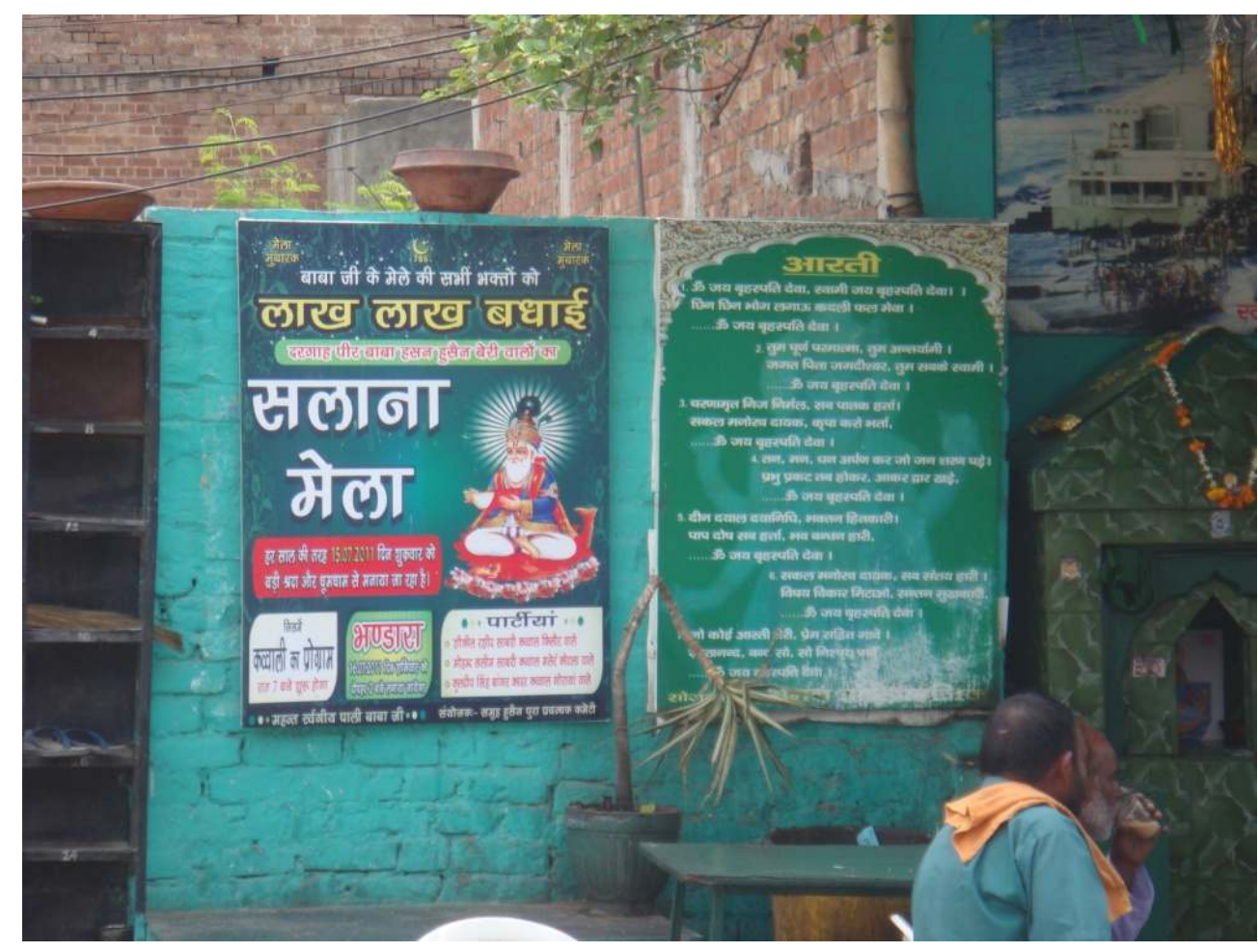

A banner announcing the mela/urs at the shrine of Baba Hasan Hussain near Hussainpura on 15 July 2011

(photo by author)

Dominique-Sila Khan suggests the tenth century as the time when the founder and exponent of Jhule Lal flourished in Sindh and spread his teaching. Therefore, it would be misleading to associate Darya Panth with much later movements like those started by Nur-ud-din Rishi (fourteenth century), Kabir (fifteenth century), Nanak or Dadu (both sixteenth century). Darya Panth was contemporaneous with Nath Panth, as "Jhulelal/ Darya Nath's sect is listed among one of the oldest orders of the Kanphata Jogis" (Briggs 1938:65; c.f. Khan 2008:76). Khan also notes the dual personality of the "liminal" tradition:

In the Nath tradition Darya Nath's dual personality is also noted, as he appears as Darya Shah or Khwaja Khizr. Islamic elements, however, seem to be prevalent in the tradition. Jhulelal's samadhi is, in fact, a Muslim tomb, and his so-called "Hindu" shrine contains no image. The custom of chaliha (forty days' fast and austerities connected with the saint's tradition) is also strongly suggestive of the Sufi chilla. (Khan 2008:76)

In the specific context of contemporary Amritsar, the role of the urban mercantile Punjabi Hindus, Muslims and Sikhs assumes significance. Khwaja Khizr thus became patron saint of the bhishtis (water carriers) of the river Indus and its tributaries, protector of boatmen, fishermen, mariners and travelers, and god of water (Rose 1911:170-71). Iconographically, Khwaja Khizr is represented as an aged man, having the aspect of a faqir , clothed entirely in green, and moving in waters with a fish as his vehicle (Coomaraswamy 1989:157). In Amritsar, his sacred shrines are situated at Katra Sher Singh, where it is managed by Rajkumar (Image 3), and at Khu Kaudiyan, where his shrine is situated along with popular iconography of the "family of Shiva" and Gugga Pir. ${ }^{27}$ Interestingly, an a rati (hymn) dedicated to Vedic deity Brihaspati at the latter's shrine is inscribed on a green board that has the popularly sacred number "786", associated with 
Islam, inscribed at the top. While the link between Varuna and Brihaspati is unclear, Islamicate influences remain entangled with representation of Vedic deities. His physical representation follows a similar iconographic template.

Image 3
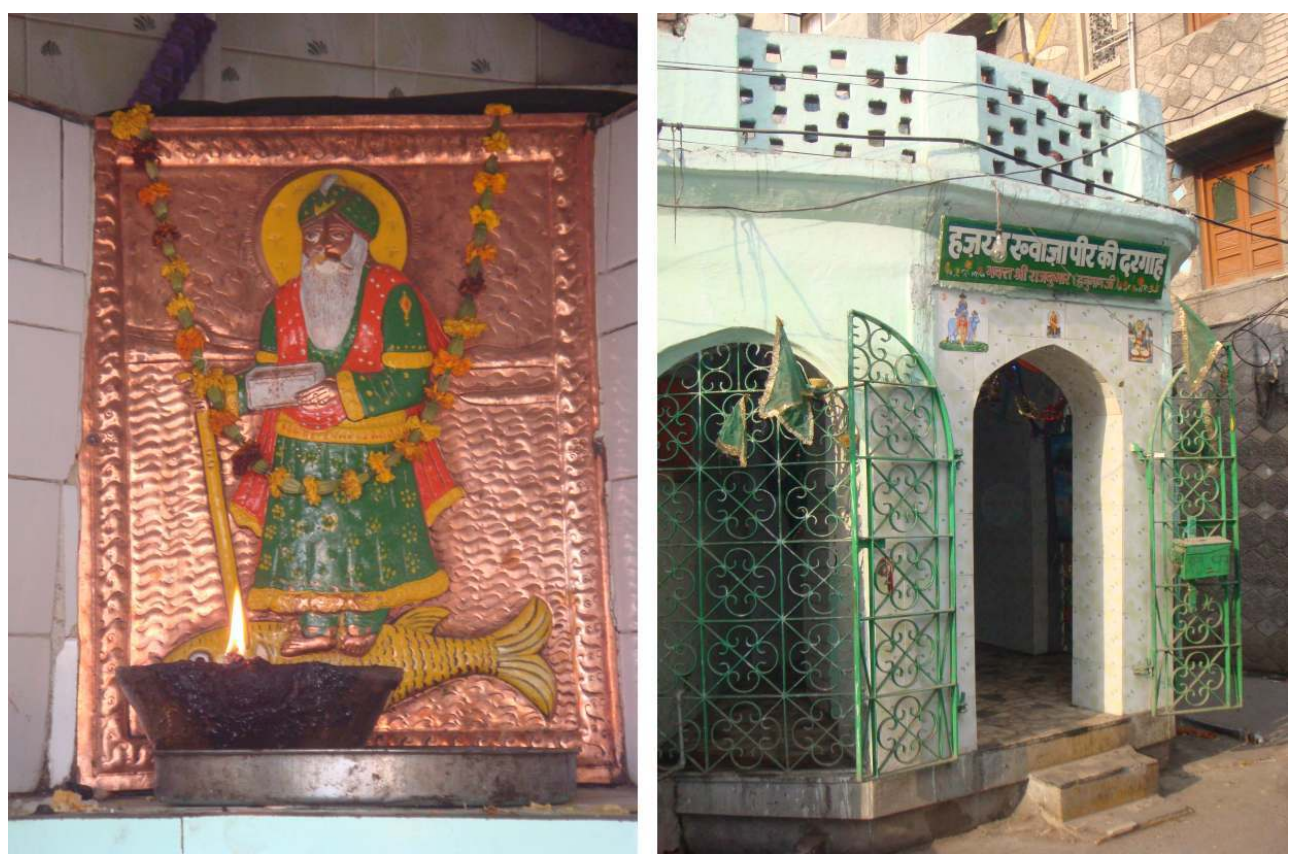

Khwaja Khizr at a shrine in Katra Sher Singh, Amritsar

(Photos by author)

In the first image above, carved out of a copper plate, Khizr is standing on a fish holding a sacred book in one hand and a mace in the other, wearing green clothes. In some other images, he is represented seated on a fish instead. He will still be holding a book, with white beard and white dress. Yet another image attempts to represent a "Hindu" iconography of Jhule Lal by placing a tilak on the forehead, yet both are located in the same shrine complex (second image above), thereby critiquing perceived separation between Khwaja Khizr and Jhule Lal.

Most wells of Amritsar are no longer extant, but images and shrines of Jhule Lal can still be located on the edges of some of these wells. In the following Image (4), placed on the edge of a well at Chowk Passian, Jhule Lal is engraved on a copper plate. This well has been in use at least until the 1950s as is attested from the inscription inside the shrine regarding maintenance (sevā) of the well, executed through the efforts of "people of the locality" of Bazaar Dharmsala Bhai Salo, Amritsar. There are several shrines dedicated to Khwaja Khizr outside the walled city too. One behind Durgiana Temple (a locality which was developed after the 1920's) was constructed on the top of an inactive well. Interestingly, Khizr or Jhule Lal do not appear in the existing historiography on popular practices. H.S. Bhatti's (2000) work on Folk Religion and Harjot Oberoi's (1994) seminal work Construction of Religious Boundaries do not even mention the veneration of Khizr in Punjab. 

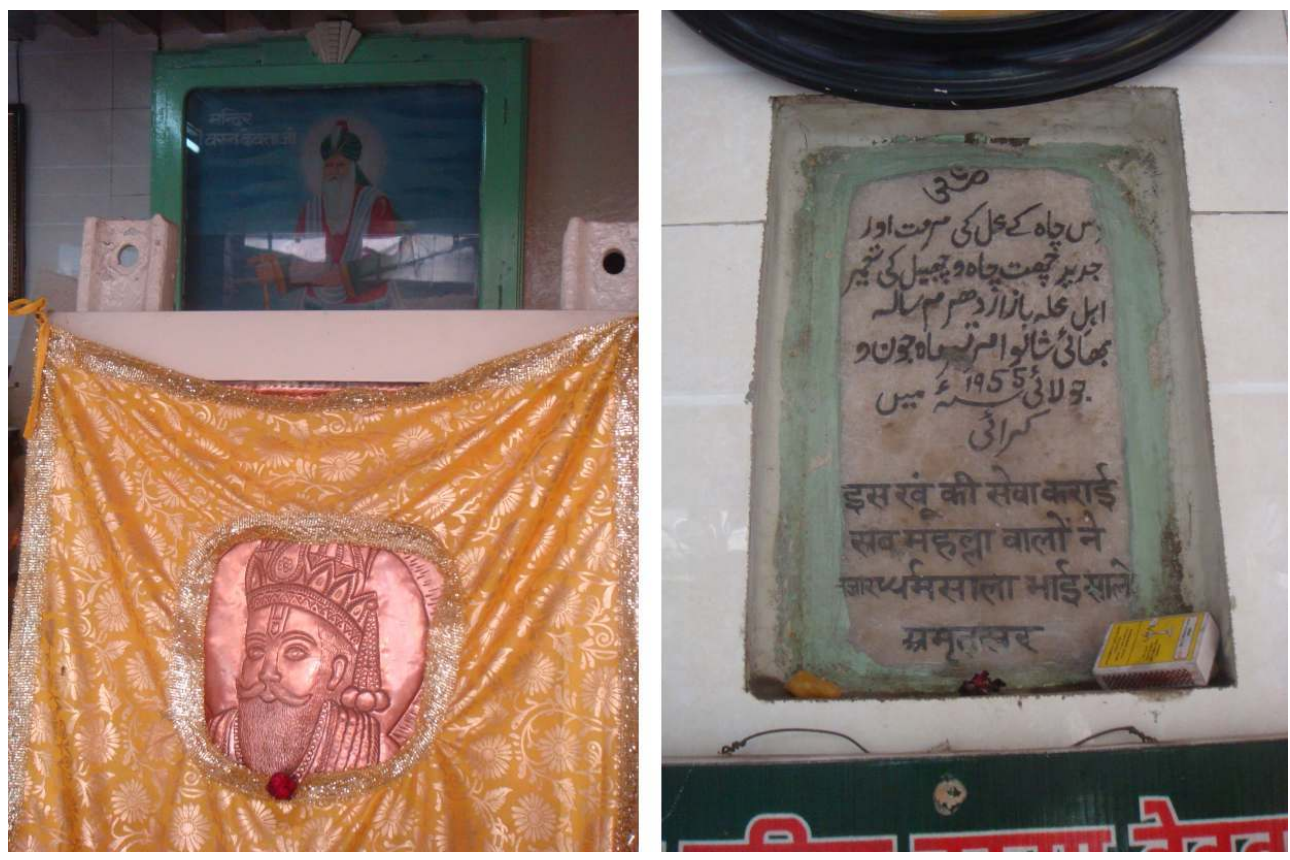

Shrine of Khizr near Chowk Passian

(Photos by author) ${ }^{28}$

The ubiquitous presence of Khwaja Khizr in Punjab resonates of the influence the tradition had in the popular veneration associated with water bodies, particularly wells. In his work on Sindhis who settled in Lucknow post-partition, Ramey argues that Jhule Lal appears predominantly as a "Hindu" deity associated with cosmology of Vedic deity Varuna (Ramey 2008:109). However, his hybrid Hindu/Muslim identity coexists in popular spaces of Punjab. It is very well accepted that Khwaja Khizr and Jhule Lal are connected deities and the former's Muslim association is recognized and at times represented along with other popular deities. This association with popular saints has a diverse manifestation and is mostly epitomized in association with the tradition of Pañj Pirs (literally "five saints").

\section{Memorializing Sakhi Sarwar, Baba Farid and Sabir Pak}

Sakhi Sarwar (d. 1174) is one of the most popularly revered saints of Punjab. A mystic of a mixed Qadiri, Suhrawardi and Chishti Sufi lineage, the following of Sakhi Sarwar must have been sizeable, for his adherents were known by varied names in different localities of colonial Punjab. ${ }^{29}$ Three major fairs which were held in the Sarwar calendar in the colonial Punjab-Dhaunkal in Gujranwala; the jhandā melā at Peshawar; and kadmon kā melà at Lahore-were complemented by similar festivities on a lesser scale at local shrines in other localities. The myths and literary narratives illustrating the life of Sakhi Sarwar link him to deities like Bhairava, a manifestation of the Hindu god Shiva, who was often represented in the legends as a messenger of the saint. Similarly, Dani, the wife of a Sidhu peasant, is among the ones who were blessed by the saint with a male child. The local votaries offered grain at each harvest, and at the fair visitors were fed for free (Rose 1911:566). 


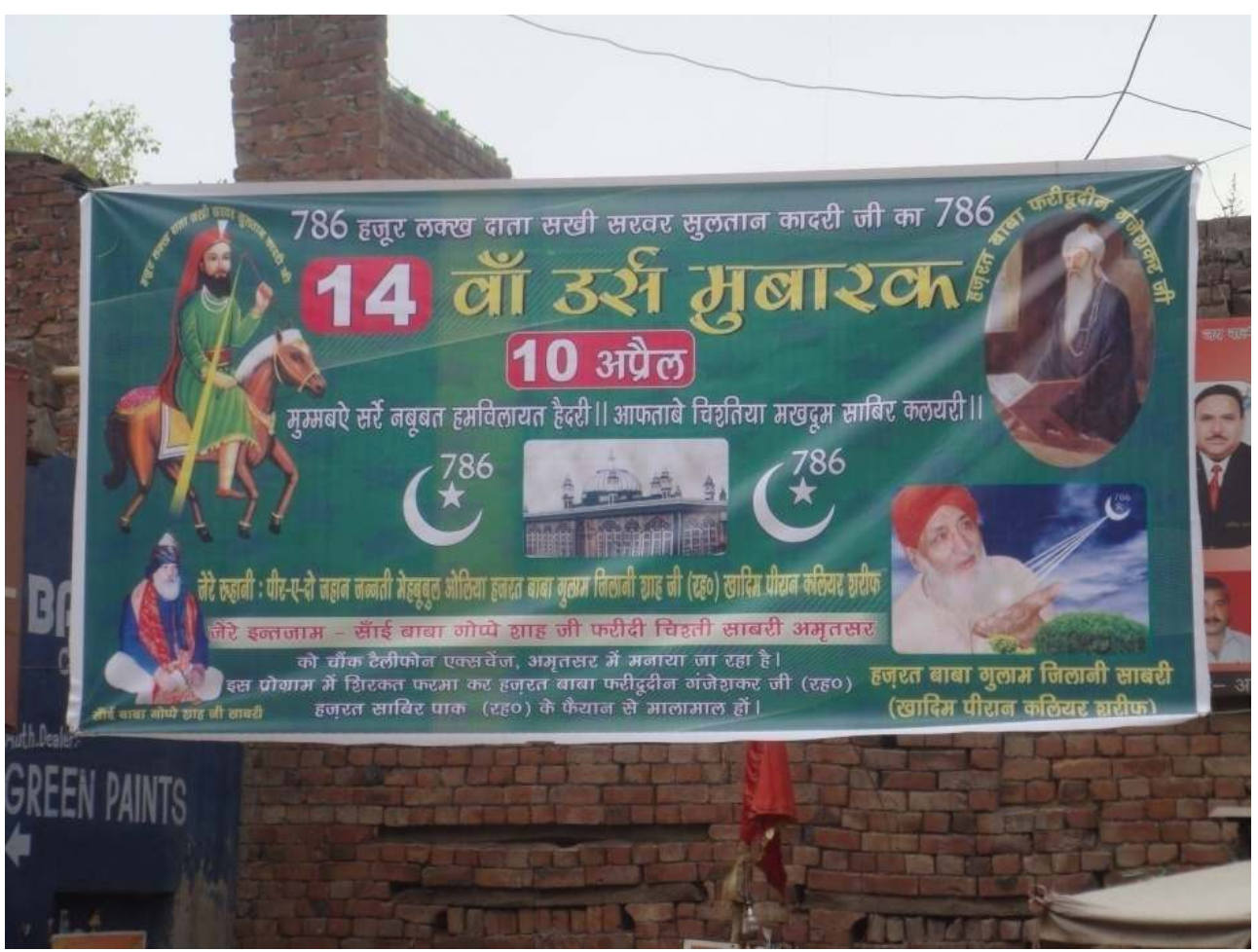

A poster announcing 14th urs celebrations of Baba Lakhdata in 2014 at Amritsar

(Photo by author)

Popular veneration of Sakhi Sarwar was subject of critique of Tat Khalsa reformers from the late nineteenth century. Amritsar and Lahore were important centers of intellectual debates on such reform. In 1896, a prominent member of the Singh Sabha movement wrote a Punjabi tract presenting a critique of veneration of Gugga Pir and Sakhi Sarwar [ Gugga Gapora Te Sultan Puara], censoring the worship of the popular saint among the "Sikhs." Harjot Oberoi argues that reform movements "constituted a sort of cultural bloc which sought to rewrite the grammar, vocabulary and syntax of culture in contemporary Punjab" (Oberoi 1987:31). According to D. Ibbetson, a British civil servant of Punjab, Sakhi Sarvar had the largest following among the pirs in the Punjab and his popularity surpassed even that of Baba Farid (Ibbetson 1883:115, cited in Oberoi 1987:37). In the 1891 census 729,131 people in the province-"Hindus", "Sikhs" and "Muslims"-stated that they were followers of Sakhi Sarvar. This number declined in subsequent census records as reform probably made individuals more conscious of their religious boundaries or Census enumerators insisted on their affiliation within the defined parameters of subsequent census surveys. Two of the most important shrines (Nigaha) in post-partition India are located in Una in Himachal Pradesh and Moga in Punjab. The Nigaha located in Dera Ghazi Khan (Pakistan) where Sakhi Sarwar was buried was target of Islamic radicals in April 2011 when a major bombing at the shrine killed more than 50 people. ${ }^{30}$

Amritsar does not have any extant shrine dedicated to Sakhi Sarwar. However, his following in the city is attested by contemporary practices. An interviewee Sunil Aggrawal, a resident of Amritsar, narrated how his father used to organize a darbār (religious gathering) at their house in the walled city that was attended by relatives and people from the community. ${ }^{31}$ The saint's public presence is visible through 
commemorative practices such as urs in his memory Sai Baba Gope Shah "Chishti Faridi Sabiri" organized annually in the walled city since $2000 .{ }^{32}$ In the year 2007, the practice of organizing a qawwāli darbār was also started. Since then Daman Sabiri, the darbāri qawwāls of Kaliyar Sharif perform at the occasion (Image 1). During annual urs organized in 2010, Sufi Rashid Mian (a Sufi ritual intermediary from Delhi), Sai Baba Mehshi Shah "Chishti Faridi Sabiri" (sajjādā nishin of a neighboring shrine Batala Sharif) and Baba Gope Shah (a ritual intermediary of Amritsar) were present. Image 6 visualizes the urs at telephone exchange chowk (intersection of streets) in the walled city of Amritsar. Baba Meshi Shah is received by Baba Gope Shah. A jubilant murid (follower) is dancing in the backdrop. The fair is attended dominantly by a non-"Muslim" audience (except for migrant Kashmiri artisans who participate). After the partition of Punjab province in 1947, the entire population of Punjabi Muslims of Amritsar migrated to Pakistan. Thus, the Muslim population at Amritsar is comprised of Kashmiri entrepreneurs and largely of artisans engaged with the woolen industry of the city, besides carpet weaving and wooden carving or migrant laborers from the Gangetic plains. The fair is organized under the banner of Anjuman Ghulame Chishtiya Sabiriya, an umbrella organization of Chishti Sabiri followers in Punjab. This organization was founded by Baba Ghulam Jilani, a khādim of Kaliyar Sharif and comprises of "Hindus" and "Sikhs" from several castes. Dr. Kittu Grewal (Jalandhar) was its president in the year 2010. The organization consists of "Hindus" (Brahmans, Khatris, Mahajans and Valmikis), "Christians" and "Sikhs." There are no Muslims in the branch at Amritsar. Thus, commemorative practices like urs in the memory of Sakhi Sarwar, Khwaja Khizr and Baba Farid play a significant role in the articulation of pre-partition memory in the streets of Amritsar.

Image 6

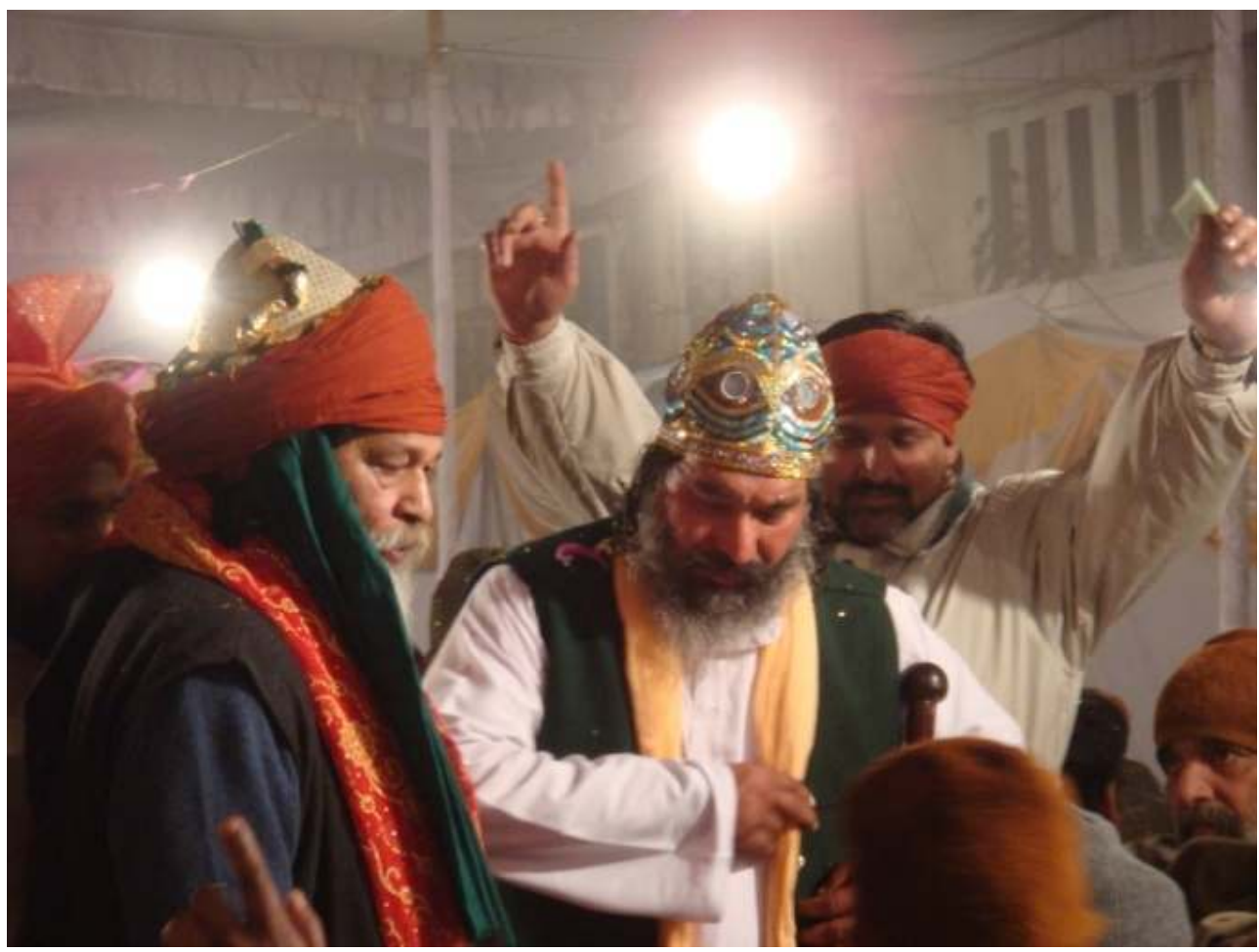

Baba Mehshi Shah (Batala Sharif) being received by Baba Gope Shah during annual Urs at Amritsar (Photo by author) 
Image 5 also includes two other saints in the poster-Baba Farid and Sabir Pak's shrine Kaliyar Sharif through its khādim Baba Ghulam Jilani Sabiri (d. 2010). Baba Farid is one of the most significant Punjabi saints. Considered to be the father of Punjabi poetry, his contribution to vernacularity of Sufi mysticism is immense. ${ }^{33}$ Farid was a disciple of Qutbuddin Bakhtiyar Kaki whose shrine is situated at Mehrauli in Delhi. ${ }^{34}$ Sabir Pak (Makhdoom Alauddin Ali Ahmed Sabir) was a direct disciple and nephew of Baba Farid and founded the Sabiriya branch of Chishti mysticism in western Uttar Pradesh. This intimate link between the shrine of Baba Farid at Pakpattan in (Pakistan) Punjab and Sabir Pak in Uttar Pradesh might have been severed post-partition. But, it finds its contemporary relevance in the spread of Sabir Pak's veneration in contemporary (Indian) Punjab. Baba Ghulam Jilani had been a frequent visitor to Amritsar post-partition and also played an important role in organizing a Sabiri fraternity in the city through the circulation of mystic literature, ideology (via ritual intermediaries and musicians) and a wider network of shrines from Amritsar, Batala to Patiala. ${ }^{35}$ Image 7 portrays the followers of the Chishti Sabiri branch in a predominantly Dalit (Valmiki) neighborhood near Lahori Gate, Amritsar. Most of the followers of this lineage assume the surname "Sabiri" and are members of an organization Anjuman Ghulame Chishtiya Sabiriya representing a new form of dissenting communitarian identity in contemporary Punjab that connects people from a wider spectrum of religious affiliations.

Image 7

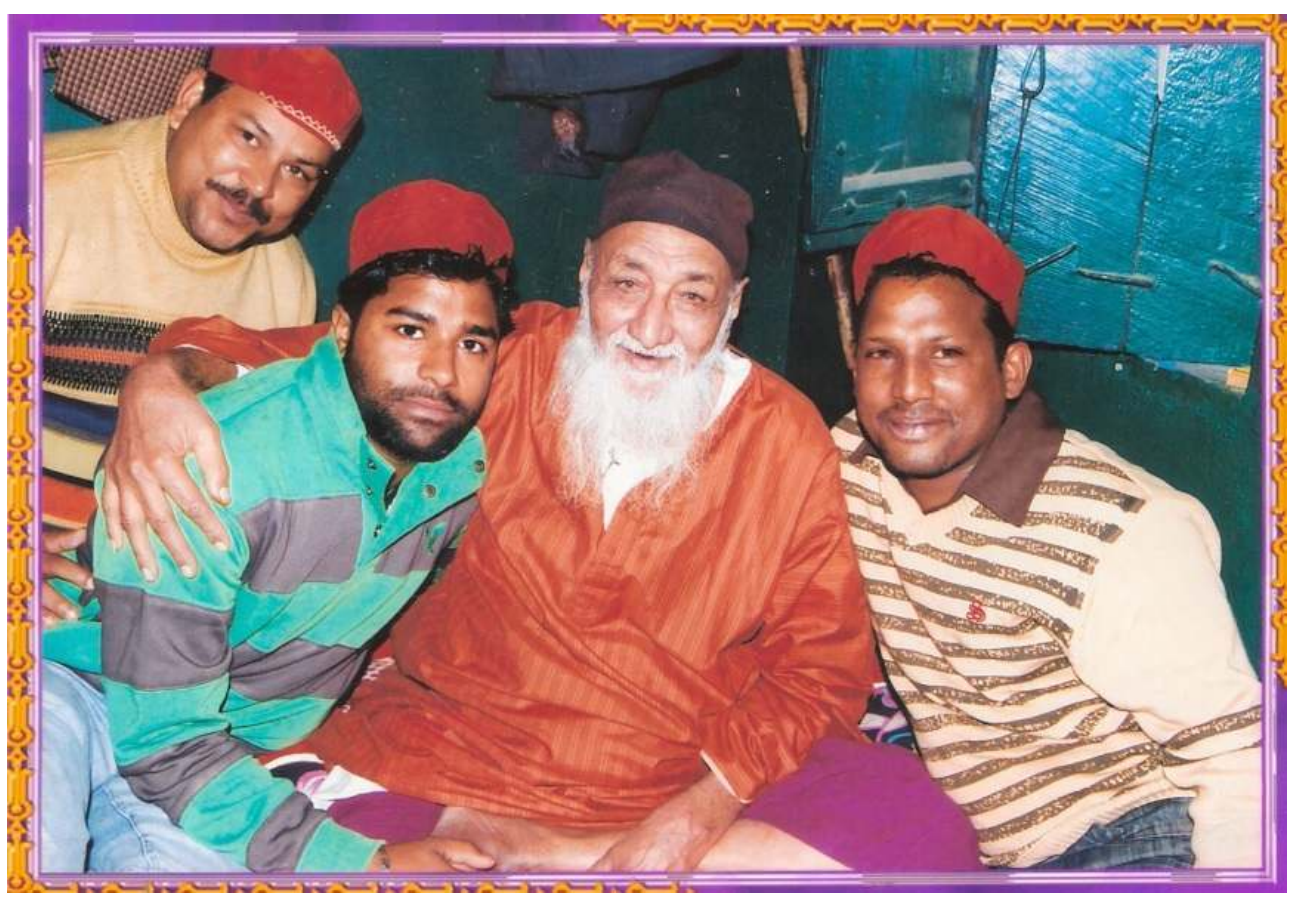

Rohit Sabiri (front left) and his friends from Amritsar with Baba Ghulam Jilani, Khadim of Kaliyar Sharif

(Photo courtesy Rohit Sabiri)

The foundation of a minor "Valmiki" shrine in the memory of Baba Farid was laid near Lahori Gate on 25 December 2007 and a chirāg (lamp) was lit by Baba Ghulam Jilani himself. Harish Sabiri has been instrumental in establishing this shrine. ${ }^{36}$ Morning and evening prayers at this shrine are performed in the Sabiri tradition. ${ }^{37}$ Every year on the 
same day an urs is organized by the community of the area which consists primarily of Dalits. The youth of the area organizes regular pilgrimage to shrines associated with Chishti Sufis like Kaliyar Sharif (Roorkee), Shamsuddin Panipatti and Bu Ali Qalandar (Panipat), Nizamuddin Auliya (New Delhi), Muinuddin Chishti (Ajmer). Several Dalit families of the locality have been worshipping pirs since the time of their grandparents and have dedicated a corner of their house to pirs. ${ }^{38}$ Among the followers of this tradition there is also the practice of using the surname Sabiri. ${ }^{39}$

\section{Conclusion}

The absence of textual narratives complicates the task of exploring popular Sufi shrines in post-partition Punjab. In the contours of Indian historiography, such shrines have long been peripheralized as a residue that lacked hagiographical accounts or any other major documented history of their existence. Yet they stood, sometimes lonely, often silent and perhaps only witness to the Partition of Punjab in 1947. At the same time, shrine spaces are imbued with memory of decades, sometime centuries, of visitation, veneration and association-both as a quotidian observer as well as guide to pilgrims and disciples. In the contours of post-partition contemporary (Indian) Punjab, popular Sufi shrines stand as the only testimony to social contours of the space pre-partition. Religious radicals have made several violent attempts to erase these remnants of the past, facilitating the electoral politics post-partition-a process of othering that has been very anxiously utilized to sustain the fragile nation-states in contemporary South Asia.

This paper explored popular Sufi shrine practices and associated semiotics and foregrounded "popular" everyday faith practices at street shrines and commemorative practices, like urs at Amritsar, to delineate the pre-partition memories of belonging in modern South Asia. The formation of Gulame Anjuman Chishtiya represents hybridization of identities in contemporary Punjab, imagined and negotiated through an ongoing process of visitation, veneration and memorialization. What is equally significant is the identification with Islamicate idioms like pir, dargāh, khānqāh, barkat, ibādat, and the construction of dargāhs, and pirkhānās that is almost universal in the contemporary popular landscape of Punjab. In the post-partition milieu, especially after the period of militancy in Punjab, these idioms have once again emerged as significant symbols of identity formation..$^{40}$ Several qawwāli darbārs organized at Amritsar bring together people from varied castes and religious affiliations (in different ladders of caste, class and gender hierarchy) adopting symbols of an alternative identity.

Kaliyar Sharif is a major marker of this unique identity which has been playing a significant role in the new wave of Chishti movement in contemporary Punjab. While earlier veneration of popular Punjabi saints like Shaikh Farid and Shaikh Haider, and various other Chishti, Qadiri, Suhrawardi Qalandari and Nashqbandi affiliations continue to be associated with Sufi shrines in the state, the presence of Sabiri branch of Chishtis is most prominent. Though networks of Sabiri shrines existed previously, linking several places from Kaliyar to Lahore. Kaliyar Sharif (Roorkee) has more recently emerged as the most significant guiding shrine for the absorption of unknown shrines with new sets of lineages and networks of Chishti pilgrimage in (Indian) Punjab. Kaliyar was also linked with important Chishti shrines at Ajmer, Panipat and Delhi. However, post-partition, Amritsar and Batala which were known for their Qadiri links with Lahore, owing to Hazrat Miyan Mir, are now known for their intimate relationship with the Chishti Sabiri 
silsilā. This new relationship is mediated through the organization of Urs in the walled city throughout the year where qawwāls from Kaliyar regularly perform. Kaliyar helps in legitimizing Punjab's relationship with Shaikh Farid and Baba Lakhdata. This new relationship is further mediated through popular "Sabiri" identity. The continued assertion of pre-partition social identities in present times is an exercise in critiquing the communal discourse of partition.

Street shrines are thus embedded in the "long history of space" of Amritsar which are neither subject nor object but rather a social reality. These are sites of living memory, "a set of relations and forms" that "explain the developments, and hence the temporal conditions" of spaces that are "subordinated to the frameworks of politics" (Lefebvre 1991:116-17). Hybrid saints like Khwaja Khizr/Jhule Lal, Baba Farid or Baba Lakhdata rupture both communal and nationalist narratives of the city space and provide an entry point beyond the historiography of conflict or narrow notions of religious boundaries. Spatially, Golden Temple and Durgiana shrines are today two extreme poles in the city space and the in-between space is occupied by a variety of sacred spaces that do not fit into the convenient identitarian tropes of contemporary historiography. Celebration of urs further open up possibilities of what Paul Coneerton (1989) calls performance of commemorative practices that enliven the longue durée of city space that defy religious boundaries. Street shrines also destabilize the polarity of sacred and profane and offer the possibility of both visual and ritual crossover.

\section{BIBLIOGRAPHY}

Ahmed, Ishtiaq. 2013. The Punjab Blooded Partitioned and Cleansed. Delhi: Rupa.

Bailey, Adrian R., Catherine Brace, and David C. Harvey. 2008. "Three Geographers in an Archive: Positions, Predilections and Passing Comment on Transient Lives." Transactions 34:254-69.

Ballard, Roger. 2006. "Popular Islam in Northern Pakistan and its Reconstruction in Urban Britain." Pp. 160-86 in Sufism in the West, edited by J. Malik and J. Hinnells. London: Routledge.

Bhatia, M. L. 2007. "Khwaja Khizr and River Cult in Medieval Sind." Pp. 167-80 in Sufism and Bhakti Movement: Eternal Relevance, edited by H. Hussain. New Delhi: Manak.

Bhatti, H. S. 2000. Folk Religion: Change and Continuity. Jaipur: Rawat.

Bigelow, Anna. 2010. Sharing the Sacred: Practising Pluralism in Muslim India. New York: Oxford University Press.

Bigelow, Anna. 2012. "Everybody's Baba: Making Space for the Other." Pp. 25-43 in Sharing the Sacra: The Politics and Pragmatics of Intercommunal Relations around Holy Places, edited by G. Bowman. New York: Berghahn Books.

Bouillier, Véronique, and Dominique-Sila Khan. 2009. “Hājji Ratan or Bābā Ratan's Multiple Identities." Journal of Indian Philosophy 37(6):559-95. 
Brace, Catherine, Adrian R. Bailey, and David C. Harvey. 2006. "Religion, Place and Space: A Framework for Investigating Historical Geographies of Religious Identities and Communities." Progress in Human Geography 30(1):28-43.

Briggs, George W. [1938] 1998. Gorakhnath and the Kanphata Yogis. Delhi: Motilal Barnarsidass. Certeau, Michel de. 1988. The Practice of Everyday Life. Translated by S. Rendall. Berkeley: University of California Press.

Chakrabarty, Dipesh. 2000. Provincializing Europe: Postcolonial Thought and Historical Difference. Princeton: Princeton University Press.

Collett, Nigel. 2006. The Butcher of Amritsar: General Reginald Dyer. New Delhi: Rupa. Connerton, Paul. 1989. How Societies Remember. Cambridge: Cambridge University Press. Coomaraswamy, Ananda K. 1989. What is Civilization? And Other Essays. Great Barrington, MA: Lindisfarne Press.

Datta, V. N. 1967. Amritsar: Past and Present. Amritsar: The Municipal Committee.

Datta, V. N., and S. Settar. 2000. Jallianwala Bagh Massacre. New Delhi: Pragati Publications. De Rogatis, Amy. 2003. Moral Geography: Maps, Missionaries and the American Frontier. New York: Columbia University Press.

Eaton, Richard M. 2002. "Indo-Muslim Traditions, 1200-1750: Towards a Framework of Study." South Asia Research 22(1):1-19.

Eliade, Mircea. 1959. The Sacred and the Profane: The Nature of Religion. Translated by W. R. Trask. New York: Harcourt.

Gauba, Anand. 1988. Amritsar: A Study in Urban History, 1840-1947. Jalandhar: ABS Publications. Gazetteer of the Amritsar District, 1892-93. [1893] 1991. Chandigarh: Revenue Department, Punjab.

Gilmartin, David. 1989. Empire and Islam: Punjab and the Making of Pakistan. Delhi: Oxford University Press.

Gramsci, Antonio. 1971. “The Study of Philosophy." Pp. 323-77 in Selections from the Prison Notebooks, edited and translated by Q. Hoare and G. N. Smith. London: Lawrence and Wishart.

Grewal, J. S. 1999. “Nabha's Ham Hindu Nahin: A Declaration of Sikh Ethnicity.” Pp. 231-54 in Sikh Identity: Continuity and Change, edited by P. Singh and N. G. Barrier. New Delhi: Manohar.

Habib, Irfan. 2005. “Jatts of Medieval Punjab.” Pp. 63-74 in Precolonial and Colonial Punjab: Society, Economy, Politics and Culture, edited by R. Grewal and S. Paul. New Delhi: Manohar. Horniman, Benjamin Guy. 1920. Amritsar and Our Duty to India. London: T. F. Unwin.

Humboldt, Wilhelm von. 1985. "On the Task of the Historian." Pp. 105-17 in The Hermeneutics Reader: Texts of the German Tradition from the Enlightenment to the Present, edited by K. MuellerVollmer. New York: Continuum.

Ibbetson, Denzil Charles Jelf. 1883. Report on the Census of the Punjab, 1881. Vol 1. Calcutta: Superintendent of Government Printing, India.

Jones, Kenneth W. 1973. "Ham Hindu Nahin: Arya-Sikh Relations, 1877-1905.” The Journal of Asian Studies 32(3):457-75.

Jones, Kenneth W. 1976. Arya Dharma: Hindu Consciousness in 19th-Century Punjab. New Delhi: Manohar. 
Kamran, Tahir. 2013. "Majlis-i-Ahrar-i-Islam: Religion, Socialism and Agitation in Action." South Asian History and Culture 4(4):465-82.

Khan, Dominique-Sila. 2008. "Jhulelal and the Identity of Indian Sindhis." Pp. 72-81 in Sindh through History and Representations: French Contributions to Sindhi Studies, edited by M. Boivin. Karachi: Oxford University Press.

Knott, Kim. 2008. "Spatial Theory and the Study of Religion.” Religion Compass 2(6):1102-16. Larson, Gerald J. 1995. India's Agony over Religion. Albany: SUNY Press.

Latour, Bruno. 1993. We Have Never Been Modern. Translated by C. Porter. Cambridge, MA: Harvard University Press.

Lefebvre, Henri. 1991. The Production of Space. Translated by D. Nicholson-Smith. Oxford: Blackwell.

Moran, Joe. 2005. Reading the Everyday. London: Routledge.

Murphy, Anne. 2012. The Materiality of the Past: History and Representation in Sikh Tradition. New York: Oxford University Press.

Oberoi, Harjot Singh. 1987. "The Worship of Pir Sakhi Sarvar: Illness, Healing and Popular Culture in the Punjab." Studies in History 3(1):29-55.

Oberoi, Harjot. 1994. The Construction of Religious Boundaries: Culture, Identity and Diversity in the Sikh Tradition. Delhi: Oxford University Press.

Ortner, Sherry B. 2006. Anthropology and Social Theory: Culture, Power and the Acting Subject.

Durham: Duke University Press.

Punjab District Gazetteer, Amritsar. 1976. Chandigarh: Revenue Department, Punjab.

Purewal, Navtej K. 2011. "Sikh/Muslim Bhai-Bhai? Towards a Social History of the Rabābi Tradition of Shabad Kïrtan." Sikh Formations: Religion, Culture, Theory 7(3):365-82.

Ramey, Steven Wesley. 2008. Hindu, Sufi, or Sikh: Contested Practices and Identifications of Sindhi Hindus in India and Beyond. New York: Palgrave Macmillan.

Rose, H. A. 1911. A Glossary of Tribes and Castes of the Punjab and North-west Frontier Province. Vol. 1. Lahore: Superintendent, Government Printing, Punjab.

Sekhon, Sant S., and K. S. Duggal. 1992. A History of Punjabi Literature. New Delhi: Sahitya Akademi. Sekhon, Sant Singh. 1969. Heer Waris Shah. New Delhi: Sahitya Akademi.

Singh, Chetan. 2005. "Well-irrigation and Socio-economic Change in Medieval Punjab." Pp. 77-95 in Precolonial and Colonial Punjab: Society, Economy, Politics and Culture, edited by R. Grewal and S. Paul. New Delhi: Manohar.

Singh, Fauja. 1984. The City of Amritsar: An Introduction. Patiala: Punjabi University.

Singh, Giani Dit. [1896] 1976. Guga Gapora Te Sultan Puara. Amritsar: Kendri Shri Guru Singh Sabha. Singh, Mohinder. 1978. The Akali Movement. New Delhi: Macmillan.

Singh, Surinder, and Ishwar Dayal Gaur. 2009. "Introduction.” Pp. 45 in Sufism in Punjab: Mystics, Literature, Shrines, edited by S. Singh and I. D. Gaur. New Delhi: Aakar.

Singh, Teja. 1922. The Gurdwara Reform Movement and the Sikh Awakening. Lahore: The Mercantile Press. 
Snehi, Yogesh. 2009. "Historicity, Orality and Lesser Shrines: Popular Culture and Change at the Dargah Panj Pir at Abohar." Pp. 402-29 in Sufism in Punjab: Mystics, Literature, Shrines, edited by S. Singh and I. D. Gaur. New Delhi: Aakar.

Snehi, Yogesh. 2017. “On the Margins of Religious Discourse.” Café Dissensus 34, April 15. Retrieved May 5, 2017 (https://cafedissensus.com/2017/04/15/on-the-margins-of-religiousdiscourse/).

Talbot, Ian, and Darshan Singh Tatla. 2006. Amritsar: Voices from between India and Pakistan. Chicago: The University of Chicago Press.

Tan, Tai Yong. 1995. “Assuaging the Sikhs: Government Responses to the Akali Movement, 19201925.” Modern Asian Studies 29(3):655-703.

The Express Tribune. 2011. "DG Khan Shrine Bombing: Death Toll Reaches 50." The Express Tribune , April 4. Retrieved February 19, 2017 (https://tribune.com.pk/story/142210/militants-attackshrine-in-dg-khan-3-dead/).

Tuteja, K. L. 1997. "Jallianwala Bagh: A Critical Juncture in the Indian National Movement." Social Scientist 25(1/2):25-61.

Veer, Peter van der. 2001. Imperial Encounters: Religion, Nation, and Empire. New Delhi: Permanent Black.

Wolper, Ethel Sara. 2011. "Khiḍr and the Changing Frontiers of the Medieval World." Medieval Encounters 17:120-46.

\section{NOTES}

1. Richard M. Eaton quotes from Gerald James Larson's India's Agony over Religion to show how Indian history continues to be problematically serialized as a "sequence of distinct cultural 'layers,' rather like the sedimentary strata successively deposited on the ocean floor" (Eaton 2002:2 cited from Larson 1995:53). Colonial engagement with the city and primacy of "Sikh" religious institutions for the concerns of colonial governance, led to an active engagement of the state with Amritsar. For a detailed reading on colonial engagement with Gurdwara reform movement see Tan (1995), and for a discussion on the colonial milieu of Gurdwara reform see Murphy (2012).

2. For a useful reading on the problems of historiographies of Punjab on either side of the international border, see Singh and Gaur (2009:31-34).

3. See Bigelow (2012) for a discussion on veneration of Baba Farid in Faridkot and Purewal (2011) for the Rababi legacy of Bhai Chand.

4. See Gilmartin (1989) and Ahmed (2013).

5. One such tract literature was Gugga Gapora Te Sultan Puara written by Giani Dit Singh (1976).

6. For a discussion on Shahidganj Mosque see Kamran (2013).

7. For a detailed reading on a Singh Sabha pamphlet "Hum Hindu Nahin," see Grewal (1999) and Jones (1973).

8. For Lefebvre, the dialectical aspects in which space is perceived, conceived and lived is constitutive of three aspects; spatial practice (perceived space), representations of space (conceived space) and spaces of representation (lived space). These three aspects provide useful tools for thinking about how people experience the spaces they inhabit and use and represent space (Knott 2008:11).

9. In their study of Methodists, Brace et.al (2006) argue that "it is necessary to move beyond the spaces of the church or chapel and pay attention to the links between community work and 
religious belief by focusing on the everyday, and often banal, formal and informal practices of Methodists, from involvement in education, charities and autodidactic cultures, to the organization of sports and social events" (32-33). In a similar vein, we should seek to look for informal practices at popular Sufi shrines to understand their multiple points of contact with social space. For instance, the practice of dangal (wrestling) competition during urs is one significant way in which the distinction between sacred and profane become irrelevant. Theoretically, the division between sacred and profane has followed the oriental trajectory of sacred texts. However, this separation is not tenable in popular spaces where religious experience emerges out of everyday interaction.

10. Eliade's (1959) problematic usage of the axiom of sacred space as separate from ordinary, profane space, one that constitutes the "center" or axis mundi, a manifestation of the "Real" (or hierophany) has now been critiqued as a myopic separation of conjoint spaces.

11. Knott argues that the "focus on space need not mean ignoring time, as spatial theory acknowledges the intersection of the two, particularly in the context of globalization. The dynamic production of space, its diachronic extensiveness and synchronic interconnectedness, and its multiplicity of representations mean that temporal traces, movements and developments are never excluded from a spatial analysis. This is an important consideration for the study of religion with its characteristic focus on history, tradition and change" (Knott 2008:14-15).

12. It was marked by a small natural "pool of water" which was said to have been a favorite resort of Guru Nanak, the founder of Sikh faith. On the margin of this pool Guru Ram Das erected himself a hut. In 1577, he obtained a grant of the site, together with 500 bighās of land from Akbar, on the payment of Rs. 700 akbarì tankās to the zamindārs of village Tung, who owned the land (Gazetteer of the Amritsar District, 1892-93:149).

13. "Almost every village, and in large communities, every patti has its guest house, known as dharmsála among Hindús, or as a takia among Muhammadans. This is in charge of a sadhu, or, ascetic, or, with Muhammadans, of the village Kázi, who also officiates in the mosque.... Muhammadan takias are less pretentious structures, and may be only a shed for travellers, fortunate if it had a door. Fire is kept burning for those who wish to smoke, and there may be a well.... The ruined tomb or khángah of some byegone saint, decked with flags and with a recess for a small oil-lamp, will often be found beside it, and it is usually close to the village mosque. Hindu Jats who worship the saint Sarvar Sultán keep up the dome-shaped makáns which perpetuate his memory, but these are indifferently cared for." (Gazetteer of the Amritsar District, 1892-93:38).

14. "Out of 21 such Muslim religious buildings, 16 were takias big and small; located beyond the wall. Some of them had khankahs also attached with them like takia and khankah Shorewala; another near Gobindgarh Fort; Sipahi Shah wala; one outside Lohgarh Gate with two pucca buildings, with burj and one of Shaker Shah. There were three Kabristans, two outside Gate Rambagh and one outside Gilwali Gate" (Gauba 1988:16).

15. However, one might also bear in mind the role played by the sajjāāa nishins of several major Sufi shrines in the movement for partition and demand for Pakistan in the 1940s (see Gilmartin 1989 for further reading).

16. "The Khojas and Shaikhs among Muslims formed the chief trading class. Khowaja Muhammad shah and Mian Muhammad Jan, both shawl merchants, were the founder members of Amritsar Municipal Committee.... Many of Shaikhs had orchards or agricultural lands around the city in 1935" (Gauba 1988:268-69).

17. This gap was further widened to 421,093 considering the number of Muslims of 186 villages of the Patti subdivision that were transferred to the Amritsar Division in 1947, with an estimated 100,243 Muslims (Punjab District Gazetteer, Amritsar 1976:120). 
18. This number declined further in the census of 1961-the number of Muslims in the district was 2,401 (2,125 males and 276 females), which had very few local Punjabi Muslims (Punjab District Gazetteer, Amritsar 1976:120).

19. The historiography of reform similarly lays emphasis on the Arya Samaji critique of Islam, Christianity, Sanatan Dharma and Sikhism leading to the rise of Hindu consciousness in late nineteenth century Punjab (see Jones 1976).

20. However, there were a significant number of Sufi saint shrines that always had non-Muslim caretakers pre-partition. I have elsewhere explored these shrines too (Snehi 2017).

21. For a detailed reading on one such shrine of Pañj Pìrs at Abohar in Punjab, see Snehi (2009). Snehi details how after around a decade of remaining desolate, ritual practice at this shrine was reinstated by Ghela Ram Kamboj. Later his son Bool Chand instituted langar and presently, a large fair is held each year commemorating the memory of Pañj Pirs.

22. However, in the case of shrine of Haji Rattan in Bathinda, for instance, partition induced an end to dargāh's relationship with Naths who used to come for Baba Rattan's urs and participated in the wrestling tournaments (kushti) (Bouillier and Khan 2009:568).

23. Samā or musical evening is ubiquitous to most Sufi shrines in Punjab and is predominantly held by organising qawwāli darbārs (musical congregations).

24. Roger Ballard further narrates his observation on Sufi shrines of Doab; "Although virtually all the indigenous Muslim population of the Doab fled west to Pakistan over half a century ago, careful inspection revealed that a significant number of rural shrines were those of pirs, since the shrouds covering such well-tended tombs and the flags which flew over them were green... The largest of these shrines became hives of activity on each juma'raat (the evening preceding the Islamic day of prayer on Friday) and positively burst with energy at their annual 'urs of the saintly pir entombed within it-even though the local Muslim population had long since disappeared. It follows that virtually all those making use of the shrine belonged to local Hindu or Sikh families" (Ballard 2006:165).

25. For a detailed reading on the role played by Persian Wheel in agrarian transformation of Punjab, see Habib (2005) and Singh (2005).

26. In some other cases, the water of wells continues to define an essential everyday ritual practice among Namdharis. Their memorial near Ram Bagh in Amritsar attach special significance to well located in its premises.

27. Gugga worship is another significant aspect of saint veneration spread across the entire north Indian plains including Punjab and a major fair Chapar Mela is organised annually in the month of February at Ludhiana. The significant part of this veneration is the idiom of Pir associated with this legend. Gugga Pir is popularly represented wearing red attire, riding a white horse with a spear in one hand, followed by Bhajju Kotwal and blessing devotees with the other, welcomed with garlands by women of the household. Smaller images along with the "Five deities" above blessing Gugga from the blue heavens and a Nath saint Machendranath, depict various episodes from his life. For a detailed reading on the Punjabi legend see Rose (1911:17192).

28. The inscription says, "this well was repaired through contributions made by the entire locality of bāzār Dharmsala, Bhai Salo, Amritsar."

29. Sarvaria, Sewak Sultani, Hindu Sultani, Nigahia, Sarvar Sakhi, Sarvar Sagar, Sultani Ramrae, Sarvar Panthi, Guru Sultania, Khawaja Sarvar and Ramdasia Sultania.

30. The Express Tribune (2011).

31. Sunil Aggrawal (38 years) was interviewed on 10 June 2010 at Shimla.

32. 11th Urs Mubarak was organised on 20 January 2010 at Chowk Telephone Exchange Amritsar by Mahatma Ashwini Sabiri, Babbi Sabiri, Bagga Sabiri, Jimmy Sabiri, Prince Sabiri, Pamma Pehalwan Sabiri, Gurdip Pahelwan Sabiri, Bau Ram Sabiri, Rocky Sabiri, Vikas Sabiri, Sham Lal Sabiri, Manjit Singh Sabiri, Tinku Sabiri, Jivan Sabiri, Billa Sabiri, Vijay Sabiri, Ashwini Sabiri, 
Gulshan Sabiri and D.K. Sabiri. Interview conducted on Prince (Bharadwaj) Sabiri (40 yrs) who is a government parking contractor and Pamma Pahelwan (Valmiki) Sabiri (39 yrs) who is an ASI in Punjab Police, on 20 January 2010 at Chowk Telephone Exchange.

33. For a detailed reading on Baba Farid's contribution to Punjab's vernacular literature see Sekhon and Duggal (1992).

34. Qutbuddin Bakhtiyar Kaki (d.1235) was a direct disciple of Sheikh Muinuddin Chishti (d. 1236), the founder of Chishti mysticism in India.

35. Some major shrines related to Baba Farid are located in the Faridkot town associated with the visit of the saint and his miracles. However, both the shrines there are under the control of local managing committees. For a detailed reading of Faridkot shrines see Bigelow (2012).

36. Harish Sabiri who is a Patwari by profession and associated with Hind-Pak Dosti Manch, Amritsar was interviewed on 29 April 2010 at the shrine outside Amrik Singh Nagar, Lahori Gate, Amritsar.

37. One is amazingly struck with constant repetition of verse data karim sabir, maula karim sabir (Sabir is the giver and master) by the disciples who are primarily non-Muslims. Survey conducted at the memorial shrine of Sabir Pak at Lahori Gate, Near Amrik Singh Nagar on 29 April 2010.

38. At the house of Rohit Kumar Mattu (22 years) who works as a sweeper at DAV College, Amritsar there is a darbar (shrine) dedicated to Baba Farid, Hazrat Ali Sahib (Shere Khuda), Baba Shah Jilani of Kaliyar Sharif, Khwaja Khizar, Sabir Pak shrine, Pir Baba Nazir Shah Chishti at Kot Khalsa (Amritsar) and Hindu deities Bhole Nath and Parvati. Interviewed on 29 April 2010 at his residence outside Amrik Singh Nagar, Lahori Gate, Amritsar.

39. Karan Bhatti Sabiri ( 23 yrs) has been to Kaliyar Sharif several times since 2007, the year he assumed the surname Sabiri. Interviewed on 29 April 2010 at his residence outside Amrik Singh Nagar, Lahori Gate, Amritsar.

40. I have recently documented the experience of two Sufi shrines during the period of militancy in Indian Punjab (Snehi 2017).

\section{ABSTRACTS}

This paper explores semiotics at street shrines that foreground "popular" everyday faith and commemorative practices, like urs at Amritsar. These shrines are a blend of pre-partition and contemporary shrine practices, and hybridize identities in contemporary Punjab, imagined and negotiated through an ongoing process of visitation, veneration and memorialization. Street shrines are thus embedded in the "long history of space" of Amritsar which are neither subject nor object but rather a social reality. These shrines are, therefore, sites of living memory and rupture both communal and nationalist narratives of the city space. I argue that rather than following the "sedimentary" theories of religious change we need to consider "popular" religion as overlapping layers of religious practices that delineate the lived and the everyday and spatialize faith practices in modern South Asia. I explore the possibilities to go beyond the neat boundaries of identities that have become comfortable meta-frames of contemporary historiographies. 
INDEX

Keywords: Amritsar, spatiality, memory, popular shrines, regions

\section{AUTHOR}

YOGESH SNEHI

School of Liberal Studies, Ambedkar University Delhi 